\title{
"Subtle, vicious effects": Lillian Steele Proctor's Pioneering Investigation of Gifted African American Children in Washington, DC
}

\author{
Sevan G. Terzian* \\ College of Education, University of Florida, Gainesville, FL, USA \\ Corresponding author. Email: sterzian@coe.ufl.edu
}

\begin{abstract}
This essay examines the first detailed study of gifted African American youth: Lillian Steele Proctor's master's thesis from the late 1920s on Black children in Washington, DC. Unlike formative research on gifted children by educational psychologists, Proctor's investigation emphasized children's experiences at school, home, and community in determining their abilities, opportunities, and accomplishments. Proctor's work also anticipated African American intellectuals' critiques of racist claims about intelligence and giftedness that would flourish in the 1930s. In focusing on the nation's capital, her investigation drew from a municipality with a high proportion of African American residents that was segregated by law. Proctor pointed directly to systemic racism as both contributing to the relative invisibility of gifted African American youth and in thwarting opportunities to realize their intellectual potential. In an environment of racial subordination and segregation, these gifted children found themselves excluded from cultural resources and educational opportunities.
\end{abstract}

Keywords: gifted education; Black education; race; African Americans; intelligence testing; Washington; DC

In 1927, an eight-year-old boy named Jesse Marchant attended sixth grade in the Washington, DC, public schools. Because he had an IQ of 175, Jesse was the subject of a study of gifted children in the nation's capital. He was described as possessing "unusually good mental control," demonstrating "special facility with digits," and performing very strongly on "tests requiring powers of reasoning, judgment, and discrimination." Jesse also had a wide range of interests. He loved to read and had recently learned to play the piano. Jesse aspired to become a physician or "a high class electrician." ${ }^{2}$ His schoolteacher considered this boy a gifted child. Residing in a good neighborhood, Jesse lived with his parents, who owned a home that was "simply and tastefully furnished," adorned with musical instruments, and contained a

\footnotetext{
${ }^{1}$ Lillian Steele Proctor, "A Case Study of Thirty Superior Colored Children in Washington, D.C.," (unpublished master's thesis: University of Chicago, 1929), 74.

${ }^{2}$ Proctor, "A Case Study," 70.

(C) History of Education Society 2021. This is an Open Access article, distributed under the terms of the Creative Commons Attribution licence (http://creativecommons.org/licenses/by/4.0/), which permits unrestricted re-use, distribution, and reproduction in any medium, provided the original work is properly cited.
} 
library. The boy's parents recognized and nourished their son's extraordinary capacities from an early age. ${ }^{3}$

Unlike other accounts of gifted children in the 1920s, however, this particular investigation focused solely on African American youth. ${ }^{4}$ According to the author, an African American graduate student and social worker named Lillian Steele Proctor, Marchant gradually realized what it meant to be a person of color living in the racially segregated capital of the United States. "Jesse is beginning to question race differences as regards colored and white people," Proctor wrote. "He wanted to know why he cannot attend certain theatres or types of amusement in Washington." Proctor recounted that "when... [Jesse's] . . . parents explained in simple language that he would not be allowed to do so because of undesirable social conditions surrounding colored people in that city, he could not seem to understand. He is still puzzled about it." ${ }^{5}$

African Americans have long been underrepresented among the gifted and talented in American education. ${ }^{6}$ A host of historical scholarship has explored related aspects of this problem, and much of this research has focused on the establishment of intelligence testing in the early twentieth century. Amid dramatic immigration, urbanization, and industrialization, along with rapidly increasing school enrollments, many educators in the 1920s believed that the quantification of intelligence through the newly created IQ tests promised an efficient mechanism for sorting students into

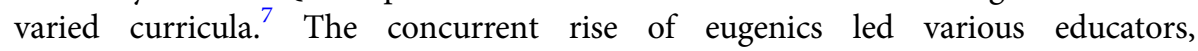

\footnotetext{
${ }^{3}$ Proctor, "A Case Study," 78.

${ }^{4}$ I employ the term "African American" rather than "Black" in this article, because all of the children in Proctor's study had been born and raised in the United States.

${ }^{5}$ Proctor, "A Case Study," 71.

${ }^{6}$ During the 2013-2014 school year, for instance, African Americans made up 15.6 percent of all students enrolled in public K-12 schools, but they accounted for only 9.9 percent of the more than three million children in gifted and talented programs in the nation's public schools. Thomas D. Snyder and Cristobal de Brey, Digest of Education Statistics 2018 (Washington, DC: National Center for Education Statistics, 2019), 88, table 204.90, https://nces.ed.gov/programs/digest/d18/tables/dt18_204.90.asp?curren$\mathrm{t}=\mathrm{yes}$. Meanwhile, African American students have been overrepresented in special education programs. In the 2018-2019 school year, 16 percent of all African American K-12 students in the US participated in federally sponsored special education, compared to 14 percent of all White students. Institute of Education Sciences, The Condition of Education 2020 (Washington, DC: National Center for Education Statistics, 2020), 41. See also Kathy-Anne Jordan, "Discourses of Difference and Overrepresentation of Black Students in Special Education," Journal of African American History 90 (Winter 2015), 128-49.

${ }^{7}$ Paul Davis Chapman, Schools as Sorters: Lewis M. Terman, Applied Psychology, and the Intelligence Testing Movement, 1890-1930 (New York: New York University Press, 1988), 3-8; Michael Sokol, "Introduction: Psychological Testing and Historical Scholarship-Questions, Contrasts, and Context," in Psychological Testing and American Society, 1890-1930, ed. Michael Sokol (New Brunswick, NJ: Rutgers University Press, 1987), 1-20; Sheldon H. White, "Conceptual Foundations of IQ Testing," Psychology, Public Policy, and Law 6, no. 1 (March 2000), 33-43; Paula S. Fass, "The IQ: A Cultural and Historical Framework," American Journal of Education 88, no. 4 (August 1980), 431-58; William Bonds Thomas, "Guidance and Testing: An Illusion of Reform in Southern Black Schools and Colleges," in Education and the Rise of the New South, ed. Ronald K. Goodenow and Arthur O. White (Boston: G. K. Hall, 1981), 169-94; Carter Julian Savage, "In the Interest of the Colored Boys': Christopher J. Atkinson, William T. Coleman, and the Extension of Boys' Club Services to African-American Communities, 1906-1931," History of Education Quarterly 51, no. 4 (Nov. 2011), 486-18; Gilbert G. Gonzalez, Chicano Education in the Era of Segregation (Philadelphia: Balch Institute Press, 1990), 62-66; Miroslava
} 
psychologists, and social reformers to view the "feeble-minded" as a threat to be contained and the "gifted" as a precious resource to be carefully nurtured. ${ }^{8}$ Benefiting from the authority of science, educational psychologists became widely influential in proclaiming that intelligence was quantifiable, inherited, and fixed over the course of a person's life. ${ }^{9}$ Furthermore, because racial minorities typically scored lower than Whites on intelligence tests, some concluded that students of color were inherently inferior in intellect. These sorts of White supremacist ideologies left pernicious legacies in American schooling. ${ }^{10}$ Additional historical studies, meanwhile, have highlighted critiques of racist claims about the nature of intelligence and giftedness.

Chavez-Garcia, "Intelligence Testing at Whittier School, 1890-1920," Pacific Historical Review 76, no. 2 (May 2007), 193-228; Carlos Kevin Blanton, "From Intellectual Deficiency to Cultural Deficiency: Mexican Americans, Testing, and Public School Policy in the American Southwest, 1920-1940," Pacific Historical Review 72, no. 1 (Feb. 2003), 39-62; and Jennifer L. Jolly, A History of American Gifted Education (New York: Routledge, 2018), 29-38.

${ }^{8}$ Clémentine Beauvais, "Californian Genius: Lewis Terman's Gifted Child in Regional Perspective," Paedagogica Historica 52, no. 6 (2016), 748-65; Roblyn Rawlins, "Raising 'Precocious' Children: From Nineteenth-Century Pathology to Twentieth-Century Potential," in When Science Encounters the Child: Education, Parenting, and Child Welfare in 20th-Century America, ed. Barbara Beatty, Emily D. Cahan, and Julia Grant (New York: Teachers College Press, 2006), 77-95; Leslie Margolin, Goodness Personified: The Emergence of Gifted Children (New York: Aldine de Grutyer, 1994); Robert E. Grinder, "The Gifted in Our Midst: By Their Divine Deeds, Neuroses, and Mental Test Scores We Have Known Them," in The Gifted and Talented: Developmental Perspectives, ed. Frances Degan Horowitz and Marion O'Brien (Washington, DC: American Psychological Association, 1985), 5-35; John Curtis Gowan, "Background and History of the Gifted-Child Movement," in The Gifted and the Creative: A Fifty-Year Perspective, ed. Julian C. Stanley, William C. George, and Cecilia H. Solano (Baltimore: Johns Hopkins University Press, 1977), 5-27; Steven Selden, "Eugenics and the Social Construction of Merit, Race and Disability," Journal of Curriculum Studies 32, no. 2 (March-April 2000), 235-52; and Leon J. Kamin, The Science and Politics of IQ (Potomac, MD: Lawrence Erlbaum, 1974), 1-29.

${ }^{9}$ Leon J. Kamin, "The Pioneers of IQ Testing," in The Bell Curve Debate: History, Documents, Opinions, ed. Russell Jacoby and Naomi Glauberman (New York: Times Books, 1995), 476-509; Clémentine Beauvais, "Teacher, Tester, Soldier, Spy: Psychologists Talk about Teachers in the Intelligence-Testing Movement, 1910s-1930s," History of Education Quarterly 57, no. 3 (Aug. 2017), 371-98; John P. Jackson Jr., Science for Segregation: Race, Law, and the Case Against Brown v. Board of Education (New York: New York University Press, 2005), 1-18; Henry L. Minton, "Lewis M. Terman and Mental Testing: In Search of the Democratic Ideal," in Sokol, Psychological Testing and American Society, 95-112; John Carson, The Measure of Merit: Talents, Intelligence and Inequality in the French and American Republics, 1750-1940 (Princeton, NJ: Princeton University Press, 2007); Stephen Gould, The Mismeasure of Man (New York: W. W. Norton, 1996); and Jennifer L. Jolly, "Pioneering Definitions and Theoretical Positions in the Field of Gifted Education," Gifted Child Today 28, no. 3 (Summer 2005), 38-44.

${ }^{10}$ Jim Wynter Porter, "A 'Precious Minority': Constructing the 'Gifted' and 'Academically Talented' Student in the Era of Brown v. Board of Education and the National Defense Education Act," Isis 108, no. 3 (Sept. 2017), 581-605; Michael Ackerman, "Mental Testing and the Expansion of Educational Opportunity," History of Education Quarterly 35, no. 3 (Fall 1995), 279-300; Lauren Stark, "Naming Giftedness: Whiteness and Ability Discourse in U.S. Schools," International Studies in Sociology of Education 24, no. 4 (2014), 394-14; Jackson Jr., Science for Segregation, 19-42; Jim Wynter Porter, "The Entanglement of Racism and Individualism: The US National Defense Education Act of 1958 and the Individualization of 'Intelligence' and Educational Policy," Multiethnica 38 (2018), 3-17; Robert V. Guthrie, "The Psychology of African Americans: An Historical Perspective," in Black Psychology, 4th ed., ed. Reginald L. Jones (Hampton, VA: Cobb \& Henry, 2004), 41-51; and Scott Barry Kaufman and Robert J. Sternberg, "Giftedness in the Euro-American Culture," in Conceptions of Giftedness: Socio-Cultural Perspectives, ed. S. N. Phillipson and M. McCann (Mahwah, NJ: Lawrence Erlbaum, 2007), 373-407. 
Some have pointed to counternarratives from African American intellectuals in the early twentieth century, who argued that environmental conditions or flawed measurements explained racial disparities in intelligence testing. ${ }^{11}$ Historians of African American education in the twentieth century, moreover, have identified an array of obstacles, including widespread racial segregation, negative stigmas for high achievement, and accountability measures. ${ }^{12}$ At the same time, scholars tracing African American student aspirations, attainment, and achievement have documented trends of perseverance and progress. ${ }^{13}$ Despite these robust bodies of research, historians have yet to account sufficiently for the salience of race in gifted education. This essay extends these lines of inquiry by examining the first detailed investigation of

\footnotetext{
${ }^{11}$ V. P. Franklin, "The Power to Define: African American Scholars, Activism, and Social Change, 19162015," Journal of African American History 100, no. 1 (Winter 2015), 1-25; William B. Thomas, "Black Intellectuals' Critique of Early Mental Testing: A Little-Known Saga of the 1920s," American Journal of Education 90, no. 3 (May 1982), 258-92; William B. Thomas, "Black Intellectuals, Intelligence Testing in the 1930s, and the Sociology of Knowledge," Teachers College Record 85, no. 3 (Spring 1984), 477501; John P. Jackson Jr., Social Scientists for Social Justice: Making the Case against Segregation (New York: New York University Press, 2001), 17-42; Wayne J. Urban, "The Black Scholar and Intelligence Testing: The Case of Horace Mann Bond," Journal of the History of the Behavioral Sciences 25, no. 4 (Oct. 1989), 323-34; Michael Fultz, “The Morning Cometh': African-American Periodicals, Education, and the Black Middle Class, 1900-1930," Journal of Negro History 80, no. 3 (Summer 1995), 97-112; V. P. Franklin, "The Tests Are Written for the Dogs: The Journal of Negro Education, African American Children, and the Intelligence Testing Movement in Historical Perspective," Journal of Negro Education 76, no. 3 (Summer 2007), 216-29; and Kathryn Kearney and Jené LeBlanc, "Forgotten Pioneers in the Study of Gifted African-Americans," Roeper Review 15, no. 4 (May/June 1993), 192-99. See also Donna Y. Ford and John Harris III, "On Discovering the Hidden Treasure of Gifted and Talented Black Children," Roeper Review 13, no. 1 (Sept./Oct. 1990), 27-33; and Roberta S. Myers and Terry M. Pace, "Counseling Gifted and Talented Students: Historical Perspectives and Contemporary Issues," Journal of Counseling and Development 64 (May 1986), 548-51.

${ }^{12}$ Davison Douglas, Jim Crow Moves North: The Battle over Northern School Segregation, 1865-1954 (New York: Cambridge University Press, 2005); Jeanne Theoharis, "I'd Rather Go to School in the South': How Boston's School Desegregation Complicates the Civil Rights Paradigm," in Freedom North: Black Freedom Struggles Outside the South, 1940-1980, ed. Komozi Woodward (New York: Palgrave Macmillan, 2003), 121-51; Kathryn Tyson, Integration Interrupted (Oxford, UK: Oxford University Press, 2011); Beatrice Bridglall and Edmund W. Gordon, "The Nurturance of African American Scientific Talent," Journal of African American History 89, no. 4 (Autumn 2004), 331-47; Brian D. Lozenski, "Beyond Mediocrity: The Dialects of Crisis in the Continuing Miseducation of Black Youth," Harvard Educational Review 87, no. 2 (Summer 2017), 161-85; and R. Scott Baker, "African American Education in the Age of Accountability, 1975-2005," in Using Past as Prologue: Contemporary Perspectives on African American Educational History, ed. Dionne Danns, Michelle A. Purdy, and Christopher M. Span (Charlotte, NC: Information Age Publishing, 2015), 275-305.

${ }^{13}$ See, for instance, Christopher Span and Ishwanzya D. Rivers, "Reassessing the Achievement Gap: An Intergenerational Comparison of African American Student Achievement Before and After Compensatory Education for the Elementary and Secondary Education Act (ESEA)," in Danns, Purdy, and Span, Using Past as Prologue, 307-24; Elizabeth Todd-Breland, "Barbara Sizemore and the Politics of Black Educational Achievement and Community Control, 1963-1975," Journal of African American History 100, no. 4 (Fall 2015), 636-62; Margaret Smith Crocco and Cally L. Waite, "Education and Marginality: Race and Gender in Higher Education, 1940-1955," History of Education Quarterly 47, no. 1 (Feb. 2007), 69-91; Linda M. Perkins, "Bound to Them By a Common Sorrow': African American Women, Higher Education, and Collective Advancement," Journal of African American History 100, no. 4 (Fall 2015), 721-47; and Mark A. Gooden, "A History of Black Achievement as Impacted by Federal Court Decisions in the Last Century," Journal of Negro Education 73, no. 3 (2004), 230-36.
} 
gifted African American youth: Proctor's unpublished master's thesis that she started in 1926 and completed in $1929 .^{14}$

Proctor's study of gifted African American children in Washington, DC, contributes to our understanding of the history of race, intelligence, and education in several ways. First, it conveyed conflicting ideas about the importance of environment and heredity in defining a person's intellectual potential and determining one's life prospects. On one hand, Proctor's work was distinct from most research of intellectually "superior" youth in the years following World War I. Most of the formative investigations of gifted children-led by Lewis Terman at Stanford University and Leta Hollingworth at Teachers College-had emphasized the importance of hereditary intelligence and tended to diminish the environmental contexts in which such children lived. ${ }^{15}$ Oriented as a social worker rather than an educational psychologist, Proctor instead accented the significance of children's experiences at school, home, and community in determining their abilities, opportunities, and accomplishments. In this respect, her views on giftedness appeared to deviate from hereditarian notions of intelligence. On the other hand, Proctor echoed some of the assumptions of leading educational psychologists that giftedness was innately conceived and that gifted people were valuable societal resources. "We ascribe creative powers and the bulk of real contributions to individuals of superior ability and capacity," Proctor wrote. "Continued progress of any group rests in great measure upon its recognition, stimulation and development of the leadership, creative ability and innate power to achieve found in its members." ${ }^{16}$ In this respect, Proctor's views on the nature of giftedness appeared to align with hereditarian notions of intelligence.

Second, Proctor's work was prototypical in anticipating African American intellectuals' critiques of racist claims about intelligence and giftedness that would flourish in the 1930s. Educational researchers in the 1920s often asserted that the relative absence of gifted African American youth resulted from their innate intellectual inferiority to Whites-part of a long-standing and pernicious ideology that educational scholars Derrick Darby and John Rury have termed, "the color of mind." In a 1924 study on gifted youth, for instance, Terman proclaimed that "the proportion of Mexican, Spanish, Italian, Portuguese, and Negro origin is very

\footnotetext{
${ }^{14}$ Horace Mann Bond published a brief essay on highly intelligent African American children several years before Proctor completed her study. Bond argued that Black educators should administer intelligence tests to Black students in order to create equitable testing conditions. See Horace Mann Bond, "Some Exceptional Negro Children," The Crisis 34, no. 8 (Oct. 1927), 256-59, 280.

${ }^{15} \mathrm{On}$ hereditarian explanations of "superior" intelligence following World War I, see Beauvais, "Californian Genius," 748-65; Chapman, Schools as Sorters, 84-103; Carl Degler, In Search of Human Nature: The Decline and Revival of Darwinism in American Social Thought (New York: Oxford University Press, 1991), 128-29; Jennifer L. Jolly, "Lewis Terman: Genetic Study of Genius-Elementary School Students," Gifted Child Today 31, no. 1 (Jan. 2008), 27-33; Kamin, "The Pioneers of IQ Testing," 476-509; Fass, "The IQ," 431-58; Margolin, Goodness Personified, 1-18; Minton, "Lewis M. Terman and Mental Testing," 95-112; and Rawlins, "Raising 'Precocious' Children," 77-95.

${ }^{16}$ Proctor, "A Case Study," 2.

${ }^{17}$ Derrick Darby and John Rury, The Color of Mind: Why the Origins of the Achievement Gap Matter for Justice (Chicago: University of Chicago Press, 2018).
} 
low." ${ }^{18}$ Hollingworth similarly declared in 1927 that "Negro children furnish fewer gifted individuals than white children do" in the United States and that research studies "unexceptionally show a low average of intellect among children having negro blood." ${ }^{19}$ Proctor countered such claims through her research. In focusing on Washington, DC, her investigation drew from a municipality with a high proportion of African American residents who were was segregated by law. African Americans in the nation's capital also had considerably little influence over their children's schooling. Proctor pointed directly to systemic racism in American society as both contributing to the relative invisibility of gifted African American youth and thwarting opportunities to realize their intellectual potential. Her pioneering investigation from the late 1920s thus exposed some of the racist features of gifted education in its formative years. Taken together, Proctor simultaneously criticized systemic racism in gifted education while she reflected dominant conceptions of high intelligence as inherited and fixed that had typically cast people of color as intellectually inferior.

\section{A Social Worker Turns to Schools}

Born in 1899, Lillian Steele Proctor was raised in a socially prominent family in Atlanta. Her father was an esteemed pastor in the Congregationalist church, and her mother founded the city's first public kindergarten. Both of Proctor's parents were graduates of Fisk University-an exceptional distinction in the late nineteenth century when even secondary schooling for African Americans was rare. Despite her family's prestige, Proctor became keenly aware of and bitter about racial injustices and the limitations they placed on people of color. As a young woman, Proctor attended Fisk, joined the National Urban League upon graduation, and eventually won a scholarship to study in the Graduate School of Social Service Administration at the University of Chicago. While pursuing her master's degree, Proctor engaged in social casework for the United Charities of Chicago for more than three years. She subsequently moved to the nation's capital and secured a position in the research department of Washington, DC's racially segregated public schools. After several years of working with mentally and developmentally challenged African American children, Proctor became interested in gifted African American students, which ultimately informed her master's thesis. ${ }^{20}$ Proctor's professional experience and intellectual orientation as a social worker distinguished her approach from most educational psychologists in the 1920s in that she carefully considered the home environments, school histories, and social experiences of these gifted children in their community contexts.

As the first known study of its kind, Proctor sought "to lay a foundation" for future knowledge about gifted African American youth. Specifically, she aimed to "show through case studies the characteristics of a group of superior colored children." Part of this effort was to demonstrate that gifted African American children actually

\footnotetext{
${ }^{18}$ Lewis Terman, "The Physical and Mental Traits of Gifted Children," in The Twenty-Third Yearbook of the National Society for the Study of Education, Part I: Report of the Society's Committee on the Education of Gifted Children, ed. Guy W. Whipple (Bloomington, IL: Public School Publishing, 1924), 164.

${ }^{19}$ Leta S. Hollingworth, Gifted Children: Their Nature and Nurture (New York: Macmillan, 1927), 69-71.

${ }^{20}$ Mary Jenness, Twelve Negro Americans (New York: Friendship Press, 1936), 53-66.
} 


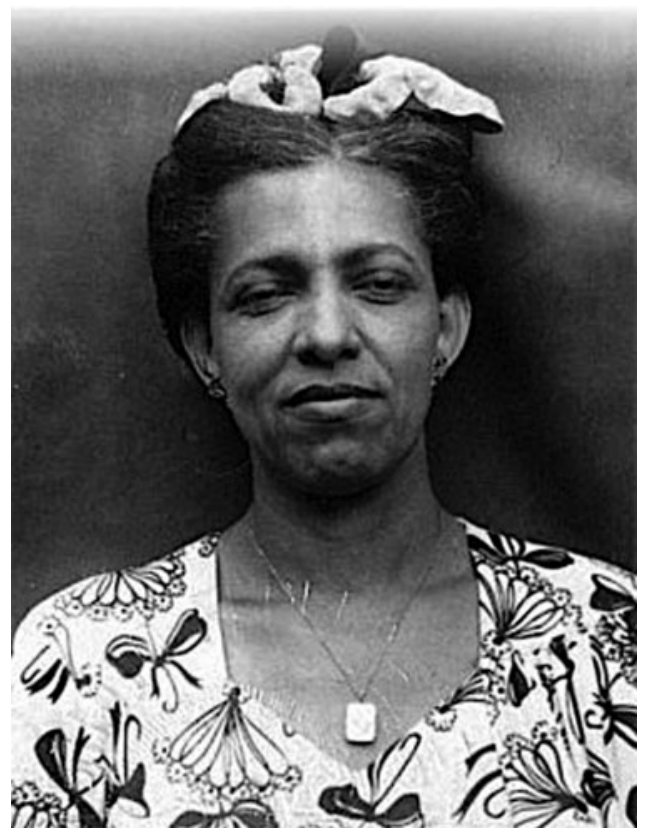

Figure 1. Lillian Steele Proctor (Falls). Photograph courtesy of House of Proctor Genealogy, https://houseofproctor.org/genealogy/index.php.

existed in an era when prominent educational psychologists were pointing to World War I Army intelligence tests as evidence that people of color were less intelligent than Whites. Proctor also wanted to discover whether and how their schools, as well as their homes and social environments, were nurturing their promising intellects and "to what extent the needs of these children are being met." Acknowledging that her relatively small sample size did not allow for generalizations, Proctor hoped that her investigation would "serve as a stimulus for further study of superior colored children." Equally important, Proctor intended to heighten awareness of "the colored child who is at the upper end of the intelligence scale" and to expose the lack of adequate educational provisions for all gifted students in the nation's capital. ${ }^{21}$

Proctor believed that her project assumed distinct urgency for African Americans "because of the opposition which the colored man meets in his efforts toward mental and social development." ${ }^{\prime 22}$ Echoing some of the social and political views articulated by W. E. B. Du Bois, she contended that the fate of all African Americans depended on the education and enlightened leadership of the most talented people of their race. ${ }^{23}$ Public schools, as "the universal agent of education to the larger group of colored children," were the most appropriate sites for discovering and supporting

\footnotetext{
${ }^{21}$ Proctor, "A Case Study," 5.

${ }^{22}$ Proctor, "A Case Study," 1.

${ }^{23}$ W. E. B. Du Bois, "The Field and Function of the Negro College (1933)," in The Education of Black People: Ten Critiques, 1906-1960, ed. Herbert Aptheker (Amherst: University of Massachusetts Press, 1973), 87, 98-101. According to Davison Douglas, by the early 1930s, Du Bois had become skeptical that integrated schools would ever fulfill African Americans' educational needs. Voluntary separation,
} 
students with superior abilities. ${ }^{24}$ Furthermore, as African Americans were most responsible for the welfare of their own youth, Proctor thought it was "particularly fitting" for "colored workers in a public school system" to conduct investigations of African American children "of superior powers." 25 Such inquiries belonged to a larger and urgently "needed search by colored people for their own powers." ${ }^{26}$ Proctor argued that "if the colored race is to survive in our highly competitive American setting, it must become conversant with those tools held most valuable in such a setting, or develop tools of its own which that setting must recognize as valuable." ${ }^{27}$ Ultimately, African Americans' social progress rested upon "individuals of very superior capacity and of superior opportunity for development." 28

Yet virtually nothing was known about gifted African Americans or gifted African American children more specifically. Proctor acknowledged Terman's inclusion of two African Americans among the sample of one thousand gifted youth he began to study in the 1920s. But she questioned Terman's decision to search for gifted children in communities (from selected portions of California) where African Americans made up only 2 percent of the population. "This two percent," Proctor explained, "furnished only three tenths of one percent of his whole gifted group." 29 In marked contrast, African Americans made up 34 percent of the schoolchildren and 25.1 percent of the 437,571 residents living in the nation's capital-the site of her investigation. ${ }^{30}$ Community contexts and demographics mattered to Proctor, and her research directed attention to Washington, DC's distinctive economic, social, and cultural features. ${ }^{31}$

This is not to suggest that Proctor rejected educational psychologists' central criteria for quantifying intelligence in identifying gifted children. Indeed, she issued Terman's Stanford-Binet intelligence tests to twenty-six of the forty-four African American elementary schools in Washington to measure each student's IQ or "mental age." Like Terman, Hollingworth, and other researchers of the gifted, moreover, Proctor solicited teachers in nominating some of their students as gifted. This process of selection yielded thirty children aged four to twelve with IQs of 129 or higher. Once chosen, Proctor administered additional assessments to her sample, including the Stanford Achievement Test (for measuring one's "educational age") and Pintner Form Board Tests (for measuring one's capacity to be "planful"). And also like Terman, Hollingworth, and others, Proctor arranged for medical examinations to measure these children's physical characteristics. In these ways, Proctor's study of gifted African American children reflected and reinforced mainstream educational

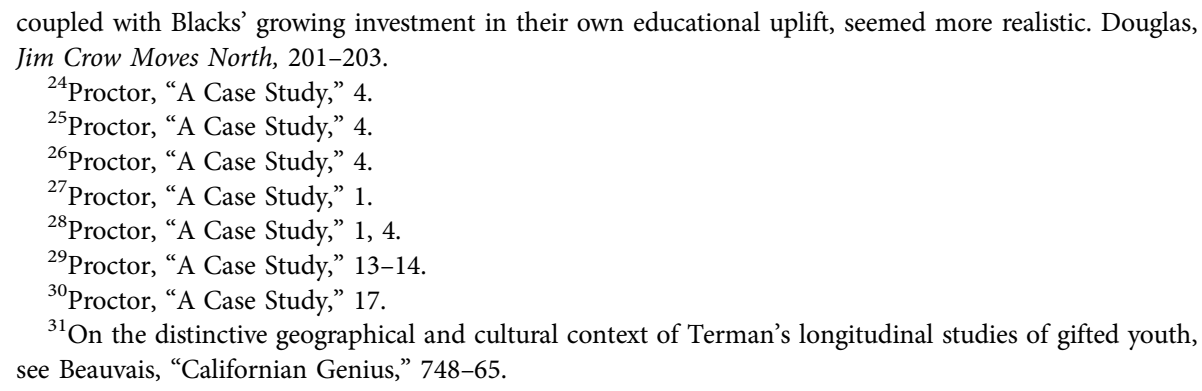


psychologists' identification criteria. Her conviction that the progress of African Americans rested upon the leadership and contributions of a select group of highly intelligent people similarly resembled central justifications for studying gifted children that had emerged in the 1920 s. $^{32}$

Despite these similarities, Proctor's investigation differed profoundly in certain aspects. More akin to the focus of a sociologist and social worker, rather than that of a psychometrician, Proctor devoted special attention to the community contexts in which the children of her study resided. Most notably, she highlighted systemic patterns of racial oppression against African Americans in the nation's capital. "Washington has an attitude and behavior toward its colored citizens that is Southern," Proctor declared, "and which results in limited opportunity for them." 33 Such discrimination was evident in the local economy, where there were "restricted opportunities for colored people in various types of employment." 34 Proctor noted, for example, that nearly half of all employed African Americans in Washington worked in domestic and personal service jobs (including servants, barbers, and janitors). By contrast, only roughly 9 percent had white-collar positions in trade or professional service sectors, with an additional 10.8 percent in clerical jobs for the federal government. ${ }^{35}$

Racial discrimination in employment opportunities was pervasive. Proctor pointed specifically to a significant portion of African American women holding degrees from the city's normal school who were working as domestic servants. All of this led her to conclude that "the number of persons in the professional and clerical groups then does not make the occupational status... as accurate an index of the cultural and educational level of the colored race in Washington as it would be in other less restricted groups." 36 In other words, many African American men and women in the nation's capital were overqualified for their jobs. ${ }^{37}$

The District of Columbia's educational system reflected these patterns of racial discrimination. African American children could only attend schools in Districts 10-13, which included one normal school, two senior high schools, four junior high schools, two vocational schools, and forty-four elementary schools. African American teachers and administrators managed these institutions, with an assistant superintendent at the head. Nonetheless, Proctor explained, these racially separate schools lacked autonomy, as they were ultimately accountable to a White superintendent who governed all of DC's schools. The absence of direct political representation for residents in the nation's capital exacerbated this problem, as it was the US Supreme Court that

\footnotetext{
${ }^{32}$ Proctor, “A Case Study," 7-11. In using Terman's intelligence tests to help identify gifted students, Proctor in a sense gave those measurements greater legitimacy. On this point, see Thomas, "Black Intellectuals, Intelligence Testing," 478; Rawlins, “Long Rows of Short Graves," 101-102; and Rawlins, "Raising 'Precocious' Children,” 86-88.

${ }^{33}$ Proctor, "A Case Study," 16.

${ }^{34}$ Proctor, “A Case Study," 17.

${ }^{35}$ Proctor, “A Case Study,” 18.

${ }^{36}$ Proctor, “A Case Study," 17.

${ }^{37}$ On racial discrimination levied against African American female educators in Washington, DC, and their organized efforts to uplift the less fortunate members of their race, see Sharon Harley, "Beyond the Classroom: The Organizational Lives of Black Female Educators in the District of Columbia, 18901930," Journal of Negro Education 51, no. 3 (Summer 1982), 254-65.
} 
appointed the school district's White and African American school board members. ${ }^{38}$

As throughout most of the United States, gifted education in Washington, DC during the 1920s was nascent, haphazard, and largely inadequate. Enrichment programs or advanced curricula in the African American schools were virtually absent. In the fall of 1925, a fundraising campaign among African American residents established a Department of Research and Measurement for Districts 10-13. Cases of gifted students accelerated to higher grades did occur occasionally once a child was tested and recommended by this Department of Research. According to Proctor, the widespread testing of all African American students aimed to reclassify children "to differentiated courses of studies," so that all would have an opportunity "to make [the] most of whatever abilities nature has given him." 39 Through this initiative, twenty-one students in grades 5-6 were identified as having superior ability and were educated separately through enriched courses, individualized pedagogy and assigned "extensive reference work." ${ }^{40}$ But this program would be quickly discontinued, and as a result, "no provision ... [was] ... made for special handling of the superior child." 41

\section{"A Case Study of Thirty Superior Colored Children"}

For her investigation of gifted African American students, Proctor selected thirty children aged four through twelve who attended kindergarten through eighth grade. All had IQs of 129 or higher on the Stanford-Binet test, which indicated mental ages considerably above their chronological ages. Their acceleration in mental age and distinction in vocabulary and language, as well as higher mental processes, were comparable to what other studies of predominantly White gifted children from the 1920 s had found. Results from the Stanford Achievement Test similarly demonstrated markedly advanced "educational ages" for all of the students in Proctor's sample, while a majority "scored Median Mental Ages above their chronological ages" on the Pintner-Paterson Form Boards Tests. Regarding academic achievement, Proctor noted that the children in her study demonstrated some acceleration in arithmetic, but were not as advanced as other gifted children in other subjects. Furthermore, Proctor concluded that the African American youth in her sample fared comparatively poorly in "general planfulness, discrimination and judgment" as evidenced in the Pintner-Paterson Form Boards Test results. ${ }^{42}$ In arranging for the physical examination of these gifted students, moreover, Proctor saw many instances of malnutrition and "enough physical defects among these thirty children to make one feel the need of special health care for them." 43 This assessment stood in contrast to reports by Terman that gifted children were physically robust. ${ }^{44}$ Nonetheless, Proctor's

\footnotetext{
${ }^{38}$ Proctor, “A Case Study," 17-22. See also Jacqueline M. Moore, Leading the Race: The Transformation of the Black Elite in the Nation's Capital, 1880-1920 (Charlottesville: University Press of Virginia, 1999).

${ }^{39}$ Proctor, "A Case Study," 27.

${ }^{40}$ Proctor, "A Case Study," 28.

${ }^{41}$ Proctor, "A Case Study," 26.

${ }^{42}$ Proctor, "A Case Study," 41.

${ }^{43}$ Proctor, "A Case Study," 34.

${ }^{44}$ Rawlins, "Raising 'Precocious' Children,” 86; and Margolin, Goodness Personified, 8, 18.
} 
evaluation criteria aligned with what the most prominent educational psychologists were using in the study of gifted children during the 1920s. ${ }^{45}$

Beyond mental and physical measurements, Proctor took great pains to examine the school, family, and community contexts in which these children lived. For each of the thirty children in her study, she consulted school records spanning a two-year period, issued surveys, and interviewed two of their teachers. Proctor found that all but four of the children were accelerated at least one grade beyond their corresponding chronological age and that their academic achievement correlated positively with their IQ scores. At the same time, she pointed to the absence of meaningful enrichment opportunities. "Though we note a tendency in the District Schools towards group instruction of homogeneous groups, greater emphasis upon individual instruction, and the provision of special facilities for retarded groups," Proctor lamented, "we find the Washington public school system making no special provision for superior children in Divisions 10-13."46 In consulting with teachers, Proctor found that nine of the students in her study received customized reading and research assignments, and in her estimation, only one of those projects was appropriate for the student's high ability and sufficiently distinct from the regular curriculum. Some of the teachers regretted that high pupil numbers and the absence of resources prevented them from accommodating the distinct needs of gifted children. A few expressed skepticism about whether the children designated as gifted were in fact intellectually superior. Such conditions and attitudes led Proctor to conclude that "generally these children are being neglected by the school administration"- a common finding from research on gifted children overall. ${ }^{47}$ Unlike some of those other studies, however, Proctor discovered that relatively few of the African American children in her investigation made excellent grades in school commensurate with their IQs. ${ }^{48}$

Much depended on the disposition of the gifted child's elementary schoolteacher. Here, Proctor identified a wide range of attitudes and accommodations. Carol Kayne's third-grade teacher, for instance, "was antagonistic toward her" and had instilled fear through negative comments about the girl's dress and physical size. ${ }^{49}$ James Edwards had a teacher who was "disgusted with him" and viewed the boy as "mentally lazy." ${ }^{\circ 0}$ By contrast, Cecilia Stanley, who sometimes suffered from a lack of academic motivation, benefited from her seventh-grade teacher's engagement and advocacy. Meanwhile, the absence of ability grouping in Washington DC's African American secondary schools presented additional challenges. Harry Chester, who had just entered high school, lacked enrichment experiences, although "some individual teachers... . [were] . . . making special effort to develop him and help him adjust in school." 51 One of Estelle Birch's new high school teachers recognized her "as a

\footnotetext{
${ }^{45}$ Proctor, "A Case Study," 32-41.

${ }^{46}$ Proctor, "A Case Study," 43.

${ }^{47}$ Proctor, “A Case Study,” 45.

${ }^{48}$ Proctor, "A Case Study," 44-46. On the relative absence of school accommodations for gifted pupils during the 1920s, see Lewis Terman, Genetic Studies of Genius, Volume 1: Mental and Physical Traits of a Thousand Gifted Children (Stanford, CA: Stanford University Press, 1925), 636.

${ }^{49}$ Proctor used pseudonyms for all of the children in her investigation.

${ }^{50}$ Proctor, “A Case Study," 189.

${ }^{51}$ Proctor, “A Case Study," 154.
} 
superior child, but the school made no special recognition of her and she received no special attention." ${ }^{52}$ Cedric Banks's second-grade teacher used him as a point of reference for the relative difficulty of a lesson. If he could not understand the topic, the teacher ruled it out as being too rigorous for the rest of the class. This did not necessarily indicate that Cedric encountered enriched learning experiences at school, however. In a similar way, Frances Saible's school, which allowed her to advance directly from first to third grade, "made no special recognition of her ability other than skipping and gave no enrichment work." 53

Beyond the school, Proctor investigated each of the gifted children's families, including their economic status, educational attainment, and domestic environment. Reflecting her orientation as a social worker, Proctor visited each child's home, observed family interactions and the child's behavior, and interviewed at least one parent about the family's history. Financial resources factored highly in her analysis as well "because of the possibilities for development it can offer" a gifted child. Proctor created a basic scale to rate a household's economic status-ranging from "good," "fairly good," and "fair"-which she admitted was "qualitative and subjective." A family with "good" economic status was financially secure, owned property, and enjoyed "comforts and luxuries such as expensive house furnishings, country homes, cars, radios, travel, entertainments." "Fairly good" status indicated a family's comfortable living through resourcefulness. Most in this category were buying homes, while some were experiencing minor "financial strain." A family with "fair" economic status endured significant "material deprivation" with major financial instability and "few luxuries." Proctor believed that a household's material resources were particularly salient for African American gifted children because "the general economic status of the colored race is lower than that of the white groups in general." As a result of widespread racial discrimination, Proctor asserted that many highly educated and cultured African American families endured low financial status. This, she believed, stood in contrast to White Americans: "Generally speaking, there is a higher degree of culture among colored families in moderate or borderline financial circumstances than among white families of the same economic level." Of the twenty-six households for the thirty children in her sample, Proctor classified twelve as "good," nine as "fairly good," and five as "fair" or "borderline." Only four of the families did not own their residences. ${ }^{54}$

In probing each gifted child's family history, in some cases as far back as pre-Emancipation, Proctor aimed to trace ancestors' occupations, migrations, and educational attainments. This was not unusual among researchers investigating the nature of superior intelligence; there had been a long-standing interest in the existence of genius or giftedness within families across generations. ${ }^{55}$ Unlike most

\footnotetext{
${ }^{52}$ Proctor, “A Case Study," 172.

${ }^{53}$ Proctor, "A Case Study," 205. On the predicament of schoolteachers with gifted students in the interwar decades, see Beauvais, "Teacher, Tester, Soldier, Spy," 371-98.

${ }^{54}$ Proctor, "A Case Study," 46-48.

${ }^{55}$ Terman, Genetic Studies of Genius, Volume 1, 85-111; Francis Galton, Hereditary Genius: An Inquiry into Its Laws and Consequences (London: Macmillan, 1892); Garland E. Allen, "Eugenics Comes to America," in The Bell Curve Debate, 441-75; Grinder, "The Gifted in Our Midst," 19-23; Abraham J. Tannenbaum, "History of Interest in the Gifted," in Education for the Gifted: The Fifty-seventh
} 
educational psychologists of the 1920s, Proctor was asserting that gifted African Americans did indeed exist. In that sense, she was challenging White supremacist claims, such as those made in Carl Brigham's 1923 A Study of American Intelligence, that African Americans' performance on the Army intelligence tests during World War I was evidence of their inherent intellectual inferiority. ${ }^{56}$ To be sure, Proctor's interest in family histories also suggests that she could have simultaneously believed that heredity determined whether a child was inherently gifted. Nonetheless, the most central difference was that all of Proctor's child subjects could trace ancestors who had been slaves in the United States. Harry Chester's paternal greatgrandmother, for instance, had been born to a White slaveholder and enslaved mother and had been known as "the most beautiful slave ever sent from Kentucky to Missouri." ${ }^{27}$ Frances Saible's paternal great-grandfather had been a White judge in Tennessee who was forced to relocate to Ohio because he was married to an African American woman. ${ }^{58}$

Parents' educational attainments also indicated varying employment status and financial security. At one end of the spectrum, Lucille Dewey's father had completed the fifth grade in rural Georgia and was a skilled laborer at the Government Printing Office in DC, while her mother had studied business at a technical high school for two years and was working in the Government Bureau of Engraving. Despite the family's fairly good economic status, Proctor described Lucille's home as "very simply and almost meagerly furnished." 59 Meanwhile, Cedric Banks's father became a messenger for a real estate office after finishing grade school, while his mother had completed only the third grade and began work as a domestic servant at the age of ten. Although Proctor described Cedric's mother as "pathetic in her ambitions for the children," she praised her for having "a degree of native intelligence and refinement that reflects itself in her children." ${ }^{\circ 0}$ Other families were more economically secure. Carol Kayne's mother was a single parent who supported her family by working as a librarian. Proctor applauded her "as being a woman of much initiative, unusual courage and devotion to her family; she has a striking personality and is possessed of a high degree of culture and intellectual capacity." ${ }^{61}$ As a librarian, Carol's mother played an active role in selecting readings for her children. And although they lived in a modest apartment, Proctor made note of "the apparent good taste and thoughtful simplicity displayed" with many books and carefully displayed pictures. ${ }^{62}$ On the upper end of the scale, Carrie Jensen's father was president of Howard University

Yearbook of the National Society for the Study of Education, Part II, ed. Nelson B. Henry (Chicago: University of Chicago Press, 1958), 27-28.

${ }^{56}$ Carl Brigham, A Study of American Intelligence (Princeton, NJ: Princeton University Press, 1923). On American social scientists' emerging critiques of Brigham and hereditarian explanations of intelligence in the late 1920s and 1930s, see Degler, In Search of Human Nature, 165-83.

${ }^{57}$ Proctor, "A Case Study," 158.

${ }^{58}$ Proctor, "A Case Study," 207.

${ }^{59}$ Proctor, "A Case Study," 224.

${ }^{60}$ Proctor, "A Case Study," 124.

${ }^{61}$ Proctor, "A Case Study," 94.

${ }^{62}$ Proctor, “A Case Study," 96. 
and "a speaker of national reputation." Carrie's family lived in a house on the university campus that included musical instruments and "a well stocked library."

Family histories and current economic status contributed to Proctor's evaluation of each gifted child's home environment. Proctor's professional and educational experience in social work led her to place a heavy emphasis on the domestic atmosphere's "importance in molding children." Despite the inherent ambiguity in rating a child's home based on one or two visits, Proctor considered herself well equipped to evaluate "factors there which contribute to personal adjustment." She established criteria for good homes, which included "provision of material necessities of life; the presence of an atmosphere of kindly and simple human relationships, and a feeling of security in them on the part of the child; training in behavior codes such as will help the child adjust well in the larger community; and training in self-direction." In some instances, she also took a family's "community activities" and societal "status" into account. ${ }^{64}$

At the top end of Proctor's scale were "cultured" families, where "the spirit of broad education is alive" and "children are consciously stimulated to breadth and depth of personal growth and personal direction." Of the twenty-six households of the thirty gifted children in her study, Proctor rated twelve as belonging to this group, all of which had home libraries and made use of public libraries. Parents with "fine personalities" and "high standards" helped their children adjust well socially and consistently provided "wide ranges of experiences rich in developmental possibilities." Material amenities also contributed to this climate of learning and support through attractive domestic furnishings, libraries, parental guidance in reading and leisure time, good use of community resources, home conversations on "vital and current subjects," and "the subtle molding of character and attitude which takes place in many intangible ways." The physical setting of such homes exuded "beauty, thought, and refinement," which for Proctor represented elite cultural standards. ${ }^{65}$

At the middle of Proctor's scale were "fairly cultured" homes, where there was "generally no special stimulation and guidance and parents rarely recognized their children's special ability." ${ }^{\prime 6}$ Nine households belonged to this group. Such residences revealed little parental effort to learn more about their children's abilities or to develop them "intellectually and socially." ${ }^{67}$ Some parents in this category were fairly well educated, but "not sufficiently alert and broad in their own interests" to raise their precocious children appropriately. ${ }^{68}$ Others had relatively little formal schooling, but still possessed "native intelligence and initiative" in seeking stimulating learning experiences outside their homes for their children. ${ }^{69}$ Again, Proctor presumed that gifted children needed exposure to life beyond the seemingly provincial setting of the African American family in order to realize their intellectual potential. ${ }^{70}$

\footnotetext{
${ }^{63}$ Proctor, "A Case Study," 139-43.

${ }^{64}$ Proctor, “A Case Study," 49-50.

${ }^{65}$ Proctor, "A Case Study," 51.

${ }^{66}$ Proctor, "A Case Study," 51.

${ }^{67}$ Proctor, "A Case Study," 51-52.

${ }^{68}$ Proctor, "A Case Study," 53.

${ }^{69}$ Proctor, "A Case Study," 53.

${ }^{70}$ Proctor, "A Case Study," 53.
} 
Finally, in "distinctly deprived" households, "a striking lack of wise guidance and provision of developmental experiences" denied children security and damaged their self-esteem. ${ }^{71}$ In a few instances, such homes had virtually no amenities for the gifted children to develop intellectually through reading, intelligent conversations, or use of community resources. In Proctor's assessment, parents in this group either suffered from mental instability or "limited knowledge and vision" in failing to raise their gifted child appropriately. Among the five households in this group, Proctor lamented the "limited knowledge and vision of the parents, ignoring the child's ability, and striking lack of guidance, or definite mishandling." 72

Proctor's careful attention to domestic contexts indicates a belief that heredity alone did not determine whether a gifted child would realize his or her potential. Her consideration of informal educational settings through the family reflected Proctor's professional orientation as a social worker. However, Proctor's evaluation criteria did little to validate African Americans' cultural expressions and intellectual traditions. They instead adhered to manifestations of high culture and implicitly White values "in relation to standards which obtain in groups recognized for their culture and not only as they obtain in colored families in Washington." ${ }^{73}$ One can infer, then, that "cultured" upbringings taught gifted African American children to adapt to a White-dominated society as it existed. By the same token, culturally deficient upbringings denied gifted children essential educational experiences at home and access to libraries, museums, lecture halls, or theaters. This marked a sort of deficit thinking on Proctor's behalf. Ironically, it aligned with some of the racist elements of intelligence testing and psychologists' claims that African Americans furnished proportionally fewer gifted people.

Beyond the home and school, Proctor paid particular attention to each gifted child's social environment in the local community. This was a factor that most prominent gifted researchers of the 1920s also acknowledged, including Terman and Hollingworth. But their hereditarian leanings led these educational psychologists to diminish its importance. Indeed, one gets little sense of the geographical, community, and social contexts within which the children in Terman's and Hollingworth's studies lived. $^{74}$ According to historian Carl Degler, Hollingworth was "a rather doctrinaire eugenicist," who believed that socioeconomic class differences were biologically determined. ${ }^{75}$ Among the twelve case studies Hollingworth featured in her longitudinal investigation of gifted children, for example, discussion of a child's family centered primarily on ancestry and placed little emphasis on the home environment. Hollingworth paid even less attention to the larger societal contexts in which each gifted child lived and made no reference at all to structures of racial discrimination in those communities. ${ }^{76}$

\footnotetext{
${ }^{71}$ Proctor, “A Case Study," 53.

${ }^{72}$ Proctor, “A Case Study," 54.

${ }^{73}$ Proctor, “A Case Study," 50-51.

${ }^{74}$ Terman, Genetic Studies of Genius, Volume 1, 61-83; Hollingworth, Gifted Children, 150-201; and Selden, "Eugenics and the Social Construction," 235-52.

${ }^{75}$ Degler, In Search of Human Nature, 129.

${ }^{76}$ See Leta Stetter Hollingworth, Children Above 180 IQ, Stanford-Binet: Origin and Development (New York: World Book, 1942), 69-223; and Leta S. Hollingworth, "Bright Students Take Care of Themselves," North American Review 243, no. 2 (Summer 1937), 261-73.
} 
For a social worker like Proctor, however, the larger community was critical in shaping gifted children's aspirations and teaching them about their appropriate roles in society. Despite differences in economic and cultural status, all of Proctor's thirty gifted children residing in the nation's capital had one vital experience in common: "the limitation of sharing fully community life in Washington because they are colored." ${ }^{\text {"77 }}$ Outright exclusion was prevalent. African Americans were not permitted to attend the theater or opera, and they encountered severe restrictions in attending musical concerts or public lectures. Such exclusion, Proctor believed, inevitably compromised African American children's "cultural development in the community."78 It is again worth noting that Proctor assumed that manifestations of high cultureimplicitly from White artists and intellectuals-were of most value. In no place did she suggest that African Americans' own cultural and artistic expressions were of greatest importance. As such, Proctor considered racial exclusion from the city's cultural amenities to be a serious hindrance to a gifted child's proper development. ${ }^{79}$

Cultural denial also took the form of legalized racial segregation, which for Proctor was singularly damaging to African American children. Regarding recreational activities, African Americans were restricted to their own playgrounds. In the realm of extracurricular programs-whether in public speaking or military drill-African American students could only compete among themselves. Furthermore, Proctor explained, "colored children are seldom, if ever, encouraged to enter, or given information about entering, various contests which are constantly presented to white children." ${ }^{\prime 80}$ As a result, African American youth found themselves largely excluded from significant group activities as participants or even as spectators. Other manifestations of cultural and intellectual discouragement abounded as well. Proctor discussed African American children's limited access to playrooms or toy sections in large department stores. "If they are not actually barred there," she lamented, "clerks will frequently discourage them by taking each toy away from them that they pick up, or keep them away from others when white children are using them freely, so that it virtually amounts to barring them." ${ }^{81}$ African American youth in the nation's capital, in other words, could not use many "public" spaces. As historian Davison Douglas explains, racial segregation in American cities beyond the South had intensified by the early twentieth century and extended to neighborhoods, public facilities, and even the schools' extracurricular activities. Proctor's portrait of the restricted leisure activities for African American children illustrates that problem vividly. ${ }^{82}$

All these forms of exclusion through segregation thwarted the "intellectual and social development" of gifted African American children. Because racial discrimination existed throughout the United States, Proctor believed that all gifted children of color were negatively impacted. She acknowledged that eleven of the thirty children in her study had made note of such racial barriers and were beginning to question them (as Proctor had done in her own childhood growing up in Atlanta). Such realizations

\footnotetext{
${ }^{77}$ Proctor, "A Case Study," 54.

${ }^{78}$ Proctor, "A Case Study," 54.

${ }^{79}$ Proctor, "A Case Study," 54.

${ }^{80}$ Proctor, "A Case Study," 55.

${ }^{81}$ Proctor, "A Case Study," 54-55.

${ }^{82}$ Douglas, Jim Crow Moves North, 136-46.
} 
caused "subtle, vicious effects on personality resulting from the habitual feeling of being barred from the use of many desirable and constructive community facilities." 83 By damaging African American children's "self-esteem, assurance and poise," Proctor contended, these forms of racial discrimination often fostered "warped and embittered attitudes." ${ }^{\prime 4}$ In focusing on populations that were almost exclusively White, by contrast, no such considerations appeared in Terman's and Hollingworth's respective studies of gifted children.

As some educational researchers in the early twentieth century discovered, many intellectually superior youth encountered various hindrances at school, home, and the community in pursuing their intellectual curiosities and professional aspirations. ${ }^{85}$ A number of children in Proctor's investigation exhibited critical awareness of the obstacle of racial discrimination in larger society. For example, Carrie Jensen, a nine-year-old in fourth grade, revealed "definite attitudes on the Negro race problems in the United States. She has always seemed to realize racial differences as they involve curtailing the freedom of colored people." 86 In response to her father's prayer at the dinner table on behalf of flood victims in Mississippi, Proctor observed that Carrie "sat quietly for a while and then said that the flood came as punishment to the white people in the South for their treatment of colored people there." ${ }^{87}$ The girl rejected her mother's rejoinder that the flood should be viewed as a natural disaster, and then she questioned the value of organized religion. From Carrie's perspective, Proctor explained, "her immediate social environment fails to impart a sense of fairness and equality of opportunity." 88 Jesse Marchant, an eight-year-old boy in sixth grade, became increasingly aware of racial restrictions in his social environment as his intellectual endeavors expanded. ${ }^{89}$ Eleven-year-old Harry Chester, who attended eighth grade, was "beginning to think of color differences as relating to colored and white people," even though his mother sought "to make him feel that there is no distinction of race." 90 Eleven-year-old Cecilia Stanley had been accelerated to seventh grade and aspired to attend college to become a music teacher and writer. Despite her intellectual acumen, Proctor viewed Cecilia as "not well balanced" in her social interactions. "She seems sensitive about her appearance and her color," Proctor observed. "She hesitates to speak to certain fair teachers on the street car or on the streets, as if afraid that they will snub her." 91

A few of the children Proctor profiled appeared relatively unaware of the extent of racial discrimination in their community. In describing eight-year-old Cedric Banks, Proctor regretted the absence of a nurturing environment at home or in school. Proctor called for better recreational exposure to cultural amenities and activities in

\footnotetext{
${ }^{83}$ Proctor, “A Case Study," 56.

${ }^{84}$ Proctor, "A Case Study," 56.

${ }^{85}$ Terman, Genetic Studies of Genius, Volume 1, 636; and Myers and Pace, "Counseling Gifted and Talented Students," 548-51.

${ }^{86}$ Proctor, "A Case Study," 134.

${ }^{87}$ Proctor, "A Case Study," 134.

${ }^{88}$ Proctor, “A Case Study," 144.

${ }^{89}$ Proctor, "A Case Study," 80.

${ }^{90}$ Proctor, "A Case Study," 153.

${ }^{91}$ Proctor, “A Case Study,” 104-105.
} 
the larger community so that Cedric could realize his intellectual potential. Even though the child was not fully cognizant of it, the practice of racial exclusion in Washington, DC, remained prevalent. "As is the case of all colored children this boy will be restricted in participating in community activities," Proctor explained, "and he will be forced to develop in this respect largely through those cultural facilities provided by his own race." ${ }^{\prime 2}$ James Edwards, who envisioned owning his own shipbuilding company with detailed accounts of all of its operations and personnel, received gentle discouragement from his mother "that he should not aspire to such a big business project, since he was colored, but that he should plan something more within his reach." This eleven-year-old boy countered that he could realize his dreams through hard work and merit. ${ }^{93}$ Because of her very light complexion, Frances Saible faced no racial restrictions on where she could go in the city and encountered no overt discrimination. "She has not yet questioned color differences within the race though she associates with children of varying complexions," Proctor observed. "Her ignorance is illustrated by her response to a child's question as to whether she was white, which was 'Yes, all over."'94 Proctor's analysis suggests that eventually these children would experience forms of systemic racial discrimination that damaged their self-esteem and compromised the realization of their high intellectual potential.

Parents of the gifted African American children in Proctor's study varied in their response to systemic forms of racial discrimination. Some sought to shield their children from the harsh realities of second-class citizenship in the nation's capital. Other parents attempted to confront the problem "by teaching the children about different races of the world and by emphasizing the fact that the attitude of a dominant race does not actually wipe out the real worth of any race." 95 Proctor thought it was significant that the latter included parents of lighter complexion who could participate in activities typically denied to African Americans. Finally, a third group of parents denied the existence of racial discrimination altogether and left it to their children to negotiate. On the whole, however, the parents of gifted children in Proctor's investigation viewed systemic racism as a symptom "of narrowness in attitudes of the people making the limitations." 96 In Proctor's estimation, all but one of the parents encouraged their children to pursue their highest professional ambitions and "to attain high standards on the basis of merit, and the philosophy that conditions will improve with time and effort, even when they do not have this faith themselves."97

All of Proctor's observations and interactions with these thirty gifted African American children, their families, and teachers led her to conclude that their intellectual, emotional, and social needs went typically unfulfilled. Culturally, "the colored social environment" provided some benefits. But for Proctor, the racial isolation caused by segregation and exclusion was limiting, because "any group becomes ingrown and narrow in proportion as it is cut off from the current life of the

\footnotetext{
${ }^{92}$ Proctor, "A Case Study," 129.

${ }^{93}$ Proctor, "A Case Study," 186-87. See also Proctor's account of Carol Kayne, 83-99.

${ }^{94}$ Proctor, “A Case Study," 204.

${ }^{95}$ Proctor, "A Case Study," 56.

${ }^{96}$ Proctor, "A Case Study," 57.

${ }^{97}$ Proctor, "A Case Study," 57.
} 
community in which it lives." ${ }^{98}$ In emphasizing the importance of home and community environments, Proctor's research deviated from most studies of gifted youth in the 1920s. It also directed attention to the damaging consequences of racial exclusion and segregation for children of color. Mainstream studies of gifted youth in the 1920s by Terman, Hollingworth, and others highlighted gifted children as intellectually superior, physically robust, socially well adjusted-and overwhelmingly White. In marked contrast, Proctor argued that gifted African American children's cumulative experiences of systemic racial oppression thwarted their social growth, self-esteem, and, ultimately, their intellectual potential. ${ }^{99}$

\section{Conclusion}

In conducting the first detailed investigation of gifted African American children, Lillian Steele Proctor hoped to establish "a foundation upon which an increasing and an accurate body of information can be built" in order to "conserve a valuable group for the colored race." ${ }^{100}$ She demonstrated that a critical mass of gifted African American youth resided in the nation's capital-in an era when the most prominent educational psychologists claimed that there were disproportionately few gifted children of color. ${ }^{101}$ Proctor documented many shared qualities suggesting intellectual equality across racial lines. Unlike most foundational studies of gifted students in the 1920s, however, Proctor stressed that the child's community contexts and manifestations of racial discrimination were critical in determining-and often thwarting - the realization of his or her intellectual potential. "Because of limitations forced upon him because of his race," she argued, the gifted African American child was especially dependent on public schools and required "broad areas of contact and freedom of opportunity to develop his powers." ${ }^{\prime 102}$ Exclusion from competitions and cultural amenities damaged their self-esteem. Job discrimination hindered many Black Washingtonians' economic security. In some cases, parents even reinforced such messages by discouraging their children from aspiring to occupations that were typically closed to African Americans. These inhibiting factors frequently fostered feelings of frustration, insecurity, and resignation among gifted African American youth. For Proctor, the absence of equal (much less equitable) educational opportunity along racial lines demonstrated the inherent racism of American gifted education.

At the same time, Proctor did not reject hereditarian views of intelligence. Proctor's inquiry into the family histories of those identified as gifted may have reflected a belief that high intelligence was primarily or perhaps exclusively inherited. She similarly evaluated children's home environments with cultural standards that

\footnotetext{
${ }^{98}$ Proctor, "A Case Study," 57.

${ }^{99}$ Proctor, "A Case Study," 57.

${ }^{100}$ Proctor, "A Case Study," 58.

${ }^{101}$ As historian John Jackson, Jr. has shown, White supremacists in the early to mid-twentieth century commissioned and appropriated some research in the social and biological sciences to demonstrate the intellectual and moral inferiority of racial minorities and justify racial segregation. Jackson Jr., Science for Segregation, 1-18.

${ }^{102}$ Proctor, “A Case Study," 58-59.
} 
reflected a dominant White society that contributed to racial injustice in Washington, DC, and throughout the United States. In identifying gifted students of color, Proctor also relied on intelligence quotients and other educational measurements that had become prominent during the 1920s. Psychometricians often argued that the results of those tests revealed the inherent intellectual inferiority of African Americans. In these ways, some aspects of Proctor's research did not directly challenge White supremacist claims of intelligence-the so-called "color of mind."

Proctor's pioneering work anticipated future studies of gifted African American youth that would emerge from the mid-1930s through the early 1940s. Specifically, a wave of research stemming from Northwestern University educational psychologist Paul Witty and two of his African American doctoral students, Martin Jenkins and Viola Theman, further demonstrated the existence and described the characteristics of gifted African American children. ${ }^{103}$ A host of African American and White social scientists in the 1930s, moreover, would levy critiques of White supremacist claims about heredity and intelligence. As Proctor had argued in her own study from the late 1920s, these researchers would highlight the salience of social environments and school settings in determining the extent to which highly intelligent children would realize their potential. ${ }^{104}$

In discrediting the concept of an "achievement gap" in schooling, educational researcher Gloria Ladson-Billings has argued that a host of historical, economic, sociopolitical, and moral practices instead created American society's "education debt" to racial minorities. This accumulating deficit has contributed to racial disparities in standardized test scores, school dropout rates, enrollments in advanced and gifted curricula, and admissions to institutions of higher education. According to Ladson-Billings, generations of racial discrimination and neglect, unequal resources and earning power, and exclusion from educational decision-making have created a moral imperative to assist those who have been racially oppressed. ${ }^{105}$ Proctor's investigation of gifted African American children in the nation's capital during the late 1920s vividly portrays elements of that emerging educational debt. In an environment of racial subordination and segregation, these highly promising children found themselves excluded from educational opportunities and cultural resources at their schools, homes, and neighborhoods. They faced the future as second-class citizens.

\footnotetext{
${ }^{103}$ Jenkins retained copies of Proctor's handwritten field notes on several of the children in her sample and followed up in hopes of learning more about their future endeavors. See, for instance, Paul A. Witty and Martin D. Jenkins, "The Educational Achievement of a Group of Gifted Negro Children," Journal of Educational Psychology 25, no. 8 (Nov. 1934), 585-97; Martin D. Jenkins, "A Socio-Psychological Study of Negro Children of Superior Intelligence," Journal of Negro Education 5, no. 2 (April 1936), 175-90; and Viola Theman and Paul Witty, "Case Studies and Genetic Records of Two Gifted Negroes," Journal of Psychology 15, no. 2 (1943), 165-81.

${ }^{104}$ Franklin, "The Tests Are Written for the Dogs," 216-18; Franklin, "The Power to Define," 1-25; Fultz, “"The Morning Cometh," 97-112; Jackson Jr., Science for Segregation, 17-42; and Degler, In Search of Human Nature, 167-86.

${ }^{105}$ Gloria Ladson-Billings, "From the Achievement Gap to the Education Debt: Understanding Achievement in U.S. Schools," Educational Researcher 35, no. 7 (Oct. 2006), 3-12.
} 
Sevan G. Terzian is Professor and UF Term Professor in the School of Teaching \& Learning at the University of Florida. He is the author of Science Education and Citizenship: Fairs, Clubs, and Talent Searches for American Youth, 1918-1958. He thanks Chris Busey, Liz Chang, Karen Graves, Michelle Kalliki, William Link, Leah Powers, Kim Tolley, Sage Wright and HEQ's anonymous reviewers for helpful feedback on this essay.

Cite this article: Sevan G. Terzian, “'Subtle, vicious effects': Lillian Steele Proctor's Pioneering Investigation of Gifted African American Children in Washington, DC," History of Education Quarterly 61, no. 3 (August 2021), 351-371. https://doi.org/10.1017/heq.2021.22. 